\title{
Visualisasi Alat Musik Tradisional Gong Waning Menggunakan Animasi 3D
}

\author{
Nurcahyani Dewi Retnowati, Kristina Nona \\ Program Studi Teknik Informatika \\ Sekolah Tinggi Teknologi Adisutjipto \\ Jl. Janti Blok R Adisucipto Yogyakarta \\ ndewiret@gmail.com
}

\begin{abstract}
Gong Waning is a traditional musical instrument of Sikka community of East Nusa Tenggara which is played by beating. In its development, not many young people who can play this instrument. Therefore it is very necessary to design and create an animated model of the introduction of traditional Gong Waning musical instruments using 3Ds.Max and on sound using unity software. The output of visualization of traditional musical instrument Gong Waning in the form of animation and sound display so hopefully can be more easily in studying and using musical instrument Gong Waning.
\end{abstract}

Keywords: animation 3D, Gong Waning, modeling

\begin{abstract}
Abstrak
Gong Waning merupakan alat musik tradisional masyarakat Sikka Nusa Tenggara Timur yang dimainkan dengan cara ditabuh. Pada perkembangannya, tidak banyak generasi muda yang bisa memainkan alat musik ini. Oleh karena itu sangat perlu untuk merancang dan membuat bentuk pemodelan animasi pengenalan alat musik Gong Waning tradisional menggunakan 3Ds.Max dan pada bunyinya menggunakan software unity. Output dari visualisasi alat musik tradisional Gong Waning berupa tampilan animasi dan bunyi sehingga diharapkan dapat lebih mudah dalam mempelajari dan menggunakan alat musik Gong Waning.
\end{abstract}

Kata Kunci: Animasi 3D, Gong Waning, pemodelan

\section{Pendahuluan}

Alat musik tradisional Gong Waning merupakan salah satu bentuk warisan nenek moyang masyarakat Sikka Nusa Tenggara Timur yang dimainkan dengan cara ditabuh. Saat ini mayoritas penikmat musik Indonesia lebih suka untuk menikmati musik moderen, dibanding dengan musik daerah. Pada hakikatnya musik daerah merupakan musik yang tumbuh dan berkembang di nusantara, tetapi pada saat ini musik-musik tersebut tidak terlalu menarik perhatian peminat musik dan kurangnya sarana sebagai tempat untuk mengembangkan musik daerah tersebut. Salah satu contoh dari banyaknya jenis-jenis musik di nusantara adalah musik Gong Waning. 
Gong Waning terdiri dari beberapa jenis instrument seperti waning (gendang). Gong Waning merupakan alat musik sejenis gendang yang terbuat dari kayu kelapa dan hanya memiliki satu membran. Alat musik ini bisasanya dimainkan sebagai pengiring tarian baik dalam acara adat maupun pertunjukan tarian menurut beberapa sumber sejarah yang ada, alat musik ini sudah ada sekitar tahun 1920-an. Upaya menarik perhatian dan minat masyarakat untuk memperkenalkan alat musik tradisional. Oleh karena itu perlu dirancang suatu animasi alat musik tradisional Gong Waning yang dapat membantu dalam pembelajaran penggunaan alat musik Gong Waning.

\section{Tinjauan Pustaka}

Mochamad Fathoni (2012) berpendapat bahwa pengembangan multimedia untuk alat musik berhasil diterapkan dengan menggunakan 3Ds Max yang memunculkan objek 3 dimensi berupa gamelan demung. Gamelan demung ini pengembangan visualisasi alat musik tradisional dengan menggunakan teknologi animasi 3D. Dengan sample gamelan demung dapat digunakan sebagai media interaktif untuk membantu mengenalkan gamelan kepada masyarakat.

Iwan Setya Nugraha (2014) dalam penelitiannya pengembangan pembelajaran alat musik piano yaitu dengan teknologi multimedia yang dibuat dengan menggunakan 3Ds.Max sebagai software untuk menghasilkan gambar 3D animasi. Hasil dari perancangan aplikasi ini adalah terealisasinya suatu aplikasi metode pembelajaran teori pada piano yang dapat mempermudah user belajar tentang chord piano.

Bowo Dwi Ariyanto.(2014) dalam penelitiannya digunakan teknologi Augmented Reality sebagai media pembelajaran untuk mempelajari Sistem Tata Surya. Pembuatan aplikasi dengan menggunakan open space 3D dan 3Ds.Max hasildari aplikasi ini berupa Sistem Tata Surya yang bergerak digunakan untuk pembelajaran anak sekolah dasar.

\section{Landasan Teori}

\subsection{Gong Waning}

Gong Waning merupakan salah satu alat musik tradisional Kabupaten Sikka Nusa Tenggara Timur. Alat musik Gong Waning ini terdiri dari dua jenis instrumen utama yaitu Gong dan Waning. Waning adalah alat musik sejenis Gendang yang terbuat dari batang kelapa dan kulit sapi/kambing yang sudah dikeringkan. Waning yang satu ini memiliki bentuk yang berbeda dengan Gendang pada umumnya dan hanya memiliki satu memberan Waning yang di gunakan biasanya terdiri dari dua jenis yaitu besar dan dodor (Gendang Kecil). Alat musik ini dulunya digunakan masyarakat untuk mengiringi proses dan tarian pada upacara adat masyarakat Sikka. Alat musik ini merupakan alat musik yang dimainkan dengan cara ditabuh (dipukul). Gong Waning ini merupakan dampak dari masuknya perdagangan dari Cina, Jawa, dan Bugis yang pada saat itu membawa alat musik Gong untuk ditukar dengan barang kerajinan atau hasil bumi masyarakat di sana. Sebelum adanya Gong di daerah Sikka, masyarakat di sana terlebih dahulu menggunakan alat musik Lettor. 


\subsection{Animasi}

Animasi adalah suatu rangkaian gambar diam secara inbeethwin dengan jumlah yang banyak bila diproyeksikan akan terlihat seolah-olah bergerak seperti dilihat pada film-film kartun di televisi maupun di layar lebar. Jadi animasi yaitu menghidupkan benda diam diproyeksikan menjadi bergerak.

Penggunaan animasi pada komputer telah dimulai dengan ditemukannya software komputer yang dapat digunakan untuk melakukan ilustrasi di komputer membuat perubahan gambar satu ke gambar berikutnya, sehingga terbentuk suatu bentuk gerakan tertentu.

\subsection{Multimedia}

Multimedia merupakan suatu konsep dan salah satu teknologi baru dalam bidang teknologi informasi, dimana dalam bentuk teks, gambar, suara, animasi, dan video disatukan dalam komputer untuk disimpan, diproses dan disajikan baik secara linier maupun interaktif dibandingkan informasi dalam bentuk teks (angka dan huruf) yang umum diperoleh dari komputer saat ini, informasi dalam bentuk multimedia yang dapat diterima dengan kedua indera penglihatan dan pendengaran, lebih mendekati bentuk aslinya dalam dunia sebenarnya. Lahirnya teknologi multimedia merupakan hasil kemajuan teknologi elektronik, komputer dan perangkat lunak, kemampuan penyimpanan dan pengolahan gambar digital dalam belasan juta warna dengan resolusi tinggi serta reproduksi suara maupun video dalam bentuk digital telah memungkinkan multimedia terjangkau oleh masyarakat umum pemakai komputer-komputer. (William Richard,2009).

\section{Perancangan dan Implementasi}

\subsection{Spesifikasi Hardware dan Software}

Perangkat keras yang digunakan dalam pembuatan sistem ini adalah:

1. Processor AMDE1

2. HDML $6730 \mathrm{M}$

3. RAM 2 GB .

4. Harddisk $640 G B$.

Perangkat lunak yang digunakan dalam pembuatan sistem ini adalah:

1. Sistem operasi Windows 7

Platform sistem operasi yang digunakan dalam pembuatan animasi Gong Waning

2. 3Ds.Max 201032 bit

Untuk membuat animasi alat musik Gong Waning beserta gerakannya

3. Unity 5.0.1f1 32 (bit)

Software ini hanya untuk menampilkan bunyi animasi Gong Waning.

4. Wondershare filmora

Software ini untuk mengedit gabungan video hasil render dari 3Ds.Max. 


\subsection{Kebutuhan Peralatan Uji Coba}

Spesifikasi perangkat keras maupun perangkat lunak harus ditentukan agar dapat menguji coba animasi alat musik yang sudah jadi yang sesuai dengan kebutuhan minimal animasi tersebut bisa jalan.

\subsubsection{Spesifikasi Hardware}

Spesifikasi Hardware yang diperlukan untuk menjalankan animasi alat musik yang akan dibuat adalah:
a. Komputer
b. Prosessor Intel Core I3@2.1GHz
c. Ram 2 GB
d. Hard disk $250 \mathrm{~GB}$

\subsubsection{Spesifikasi Software}

Spesifikasi software minimal yang diperlukan untuk menjalankan animasi alat musik yang akan dibuat adalah

a. Komputer dengan sistem operasi windows 732 bit.

b. 3Ds.Max 201032 bit

Untuk membuat animasi alat musik Gong Waning beserta gerakannya

c. Unity 5.0.1f1 32 (bit)

Software ini hanya untuk menampilkan bunyi animasi Gong Waning.

d. Wondershare filmora

Software ini untuk mengedit gabungan video hasil render dari 3Ds.Max.

\subsection{Diagram Konteks}

Diagram konteks merupakan diagram yang menjelaskan proses perjalanan data dari satu atau beberapa animasi alat musikuntuk mencapai suatu tujuan tertentu yang mana pada proses perjalanan data tersebut hanya terdapat satu proses saja yang digambarkan dalam bentuk umum. Diagram konteks aplikasi yang dibuat dapat dilihat pada gambar 1 .

Terdapat 1 entitas, yaitu pengguna yang dapat memainkan aplikasi dan membuat komposisi musik sendiri. Hasil dari komposisi musik Gong Waning tersebut berupa sebuah file Video.

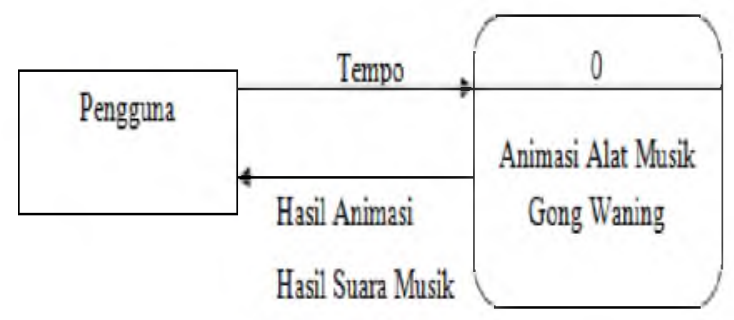

Gambar 1. Diagram Konteks Animasi 3D Alat Musik Tradisional Gong Waning 


\subsection{Diagram Alir Data Level 0}

DAD level 0 seperti yang ditampilkan pada gambar 2 merupakan pengembangan dari diagram konteks, dimana pada diagram ini menjelaskan bahwa pengguna dapat mengkomposisikan komposer dengan menginputkan tempo-tempo yang sudah dibuat animasi maka disimpan sementara ke dalam penyimpanan sementaraatau komposisi musik tersebut diproses kedalam bentuk file video animasi (3D).

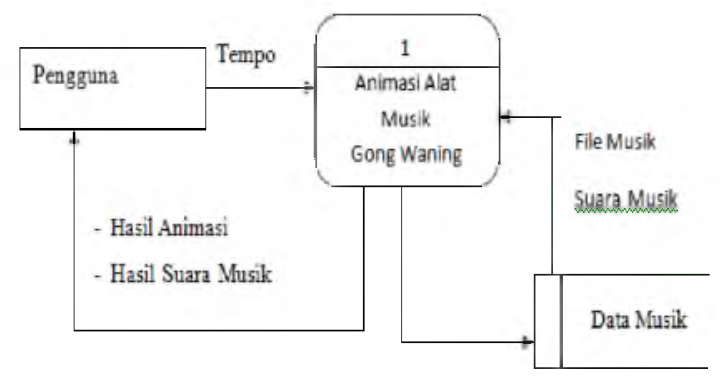

Gambar 2. DAD Level 0 Animasi 3D Alat Musik Tradisional Gong Waning

\subsection{Flowchart}

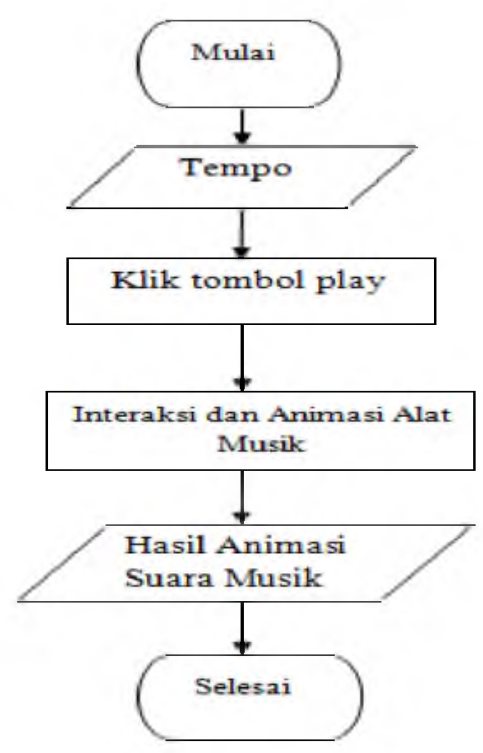

Gambar 3. Flowchart Animasi 3D Alat Musik Tradisional Gong Waning

Flowchart adalah penggambaran secara grafik dari langkah-langkah dan urut-urutan prosedur dari suatu program. Dapat dilihat pada gambar 3. 
Pada animasi Gong Waning ini rangkaian langkah-langkah pembuatannya meliputi dari awal penggunaan dari program atau dengan mengawali dengan mulai, kemudian menuju pada rangkaian bentuk model Gong Waning untuk memilih apakah program tersebut digunakan hanya untuk sekedar bermain alat musik Gong Waning saja atau untuk mengkomposisi sebuah musik (bunyi). program tersebut dibuat animasi Gong Waning saja dan program hanya dapat menghasilkan bunyi dan gerakan dari Gong Waning yang ditabuh, program dapat menghasilkaan suara dan gerakan jika pengguna sudah mengkomposisi musik, maka pengguna dapat menyimpan file tersebut ke dalam bentuk file video.

\subsection{Tahap-Tahap Pembuatan Animasi Gong Waning}

Pengembangan animasi ini meliputi tahap perancangan model, pembuatan animasi, pewarnaan, pengujian, analisa, dan penyelesaian.

1. Perancangan Model

Dalam langka ini dilakukan proses pembuatan model bentuk alat musik Gong Waning. Kemudian menyiapkan alur sistem beserta input dan outputnya beserta software dan teori pendukung.

2. Pemodelan 3D Gong Waning

Proses ini adalah membuat model alat musik Gong Waning Tradisional Kabupaten Sikka menggunakan unity dan berbasis Dekstop. Pemodelan ini menyajikan objek (3D) yaitu Gong Waning 3D tersebut terdapat informasi dan audionya.

3. Pewarnaan

Pada tahap ini memilih mewarnai hasil animasi alat musik Gong Waning sesuai yang diinginkan sehingga tampilan animasi alat musik tersebut terlihat menarik.

4. Pembuatan Animasi

Tahap pembuatan animasi ini menggerakan kayu yang akan dipukul di Gong Waning sesuai dengan tempo yang akan dimainkan proses pembuaatan animasi ini menggunakan 3Ds.Max.

5. Proses Render dan Pemasukan Sura Musik

Proses render animasi yang sudah jadi dibentuk modelnya dan yang sudah digerakan animasinya disimpan dalam format $A v i$ dan sudah jadi file video tahap selanjutnya memasukkan suara musik sesuai dengan irama tempo gerakan animasi.

6. PengujianAnimasi

Memasukkan input kedalam sistem dan memeriksa apakah output yang dihasikan sesuai yang diharapkan. Proses ini dilakukan sampai beberapa kali untuk mengetahui apabila terdapat bug / kesalahan sistem sehingga tidak didapati kesalahan pada sistem.

7. Analisa

Analisa proses ini memastikan apakah aplikasi yang dibuat dapat menjawab rumusan masalah yang dibuat dalam pendahuluan. 
8. Penyelesaian

Menarik kesimpulan dari animasi Gong Waning serta memberikan masukan untuk pengembangan selanjutnya.

Bentuk desain Gong Waning sudah jadi dan tahap selanjutnya membuat animasi gerak Gong Waning seperti gambar 4.

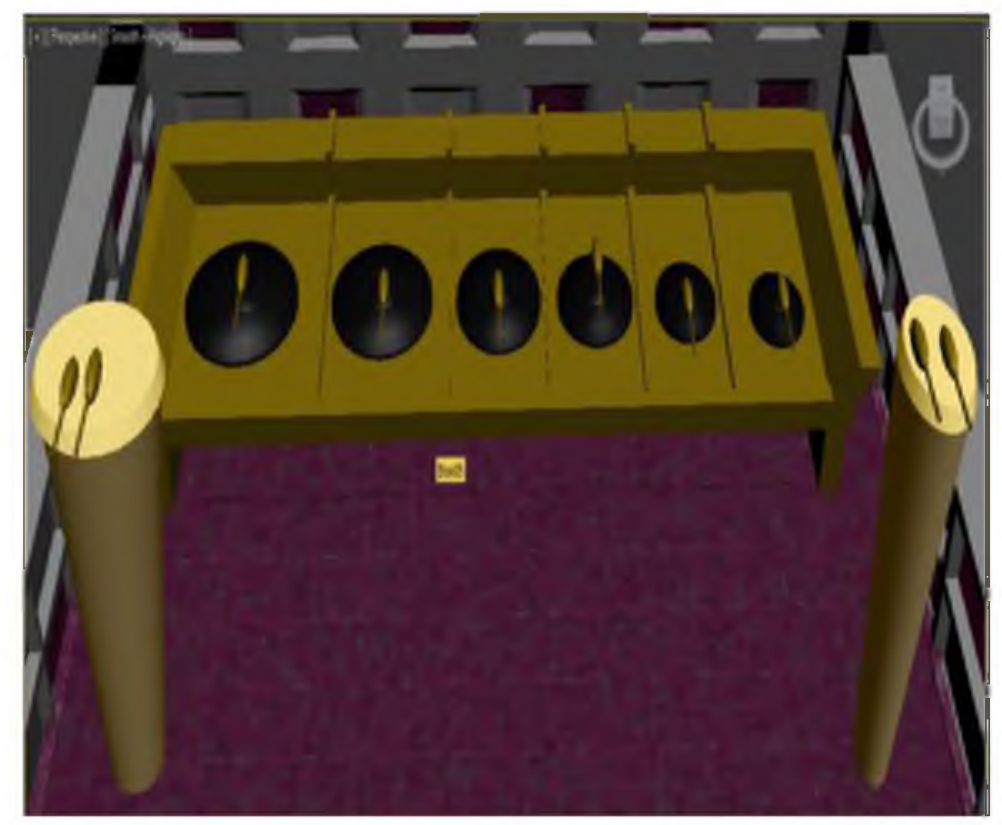

Gambar 4. Pemodelan Gong Waning Yang Sudah Jadi

Tahap selanjutnya menggerakkan animasi Gong Waning sesuai dengan irama temponya. Pada saat proses animasi bisa dikatakan gampang-gampang susah karena diperlukan imajinasi dan ketelitian dalam membuat sebuah gerakan objek. Pertama kali yang dilakukan adalah menyeting panjang frame, dengan tujuan agar lebih mudah dalam memposisikan gerakan objek dengan durasi yang panjang untuk membuat gerakan. Semakin besar frame yang di set gerakan nantinya akan semakin lambat. Dan begitupun sebaliknya.

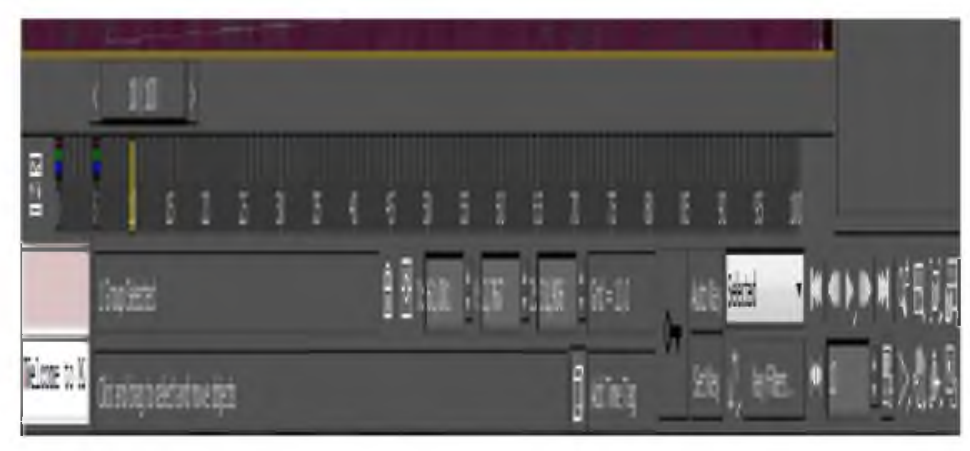

Gambar 5. Pengaturan Pada Timeline Frame 


\subsection{Proses Rendering}

Rendering adalah tahap akhir untuk mendapatkan hasil dari animasi Gong Waning yang sudah dibentuk dan sudah digerakkan animasi yang telah disusun di setiap parameternya. Setiap membuat gerakan langsung direndering menjadi filevideo berformat avi. Untuk menjadikannya satu klip atau menggabungkan hasil rendering menggunakan software editing Wondershare Filmora.

Berikut adalah langkah-langkah dalam proses render atau mengubah gambar menjadi video.

1. Pastikan objek yang ingin dirender sudah digerakan dalam timeline dan sudah di set key. Bisa dilihat pada Gambar 6.

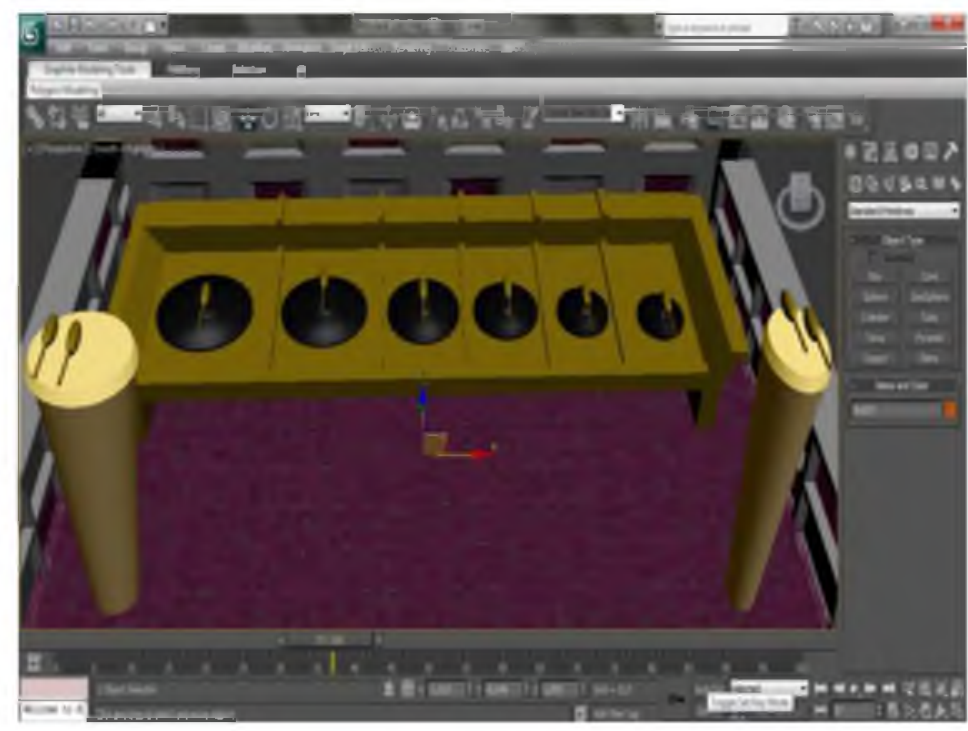

Gambar 6. Gong Waning Siap Untuk Dirender

Tahap berikut langkah- langkah awal untuk render klik menu rendering pilih render setup dapat dilihat pada gambar 7 .

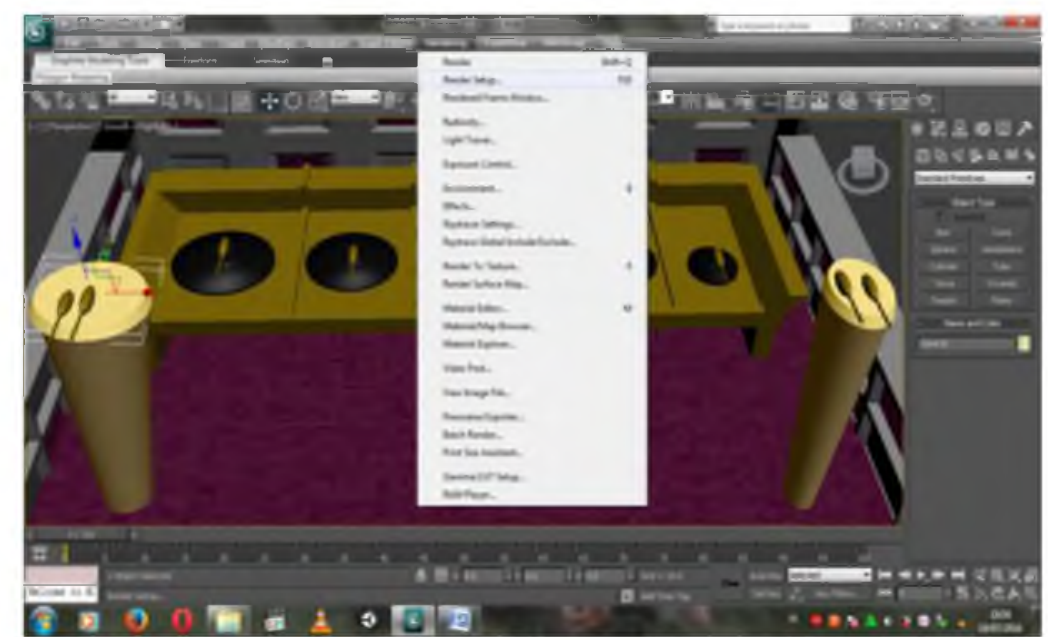

Gambar 7. Langkah-Langkah Render Gong Waning 
Setelah pilih render setup akan muncul seperti gambar 8.

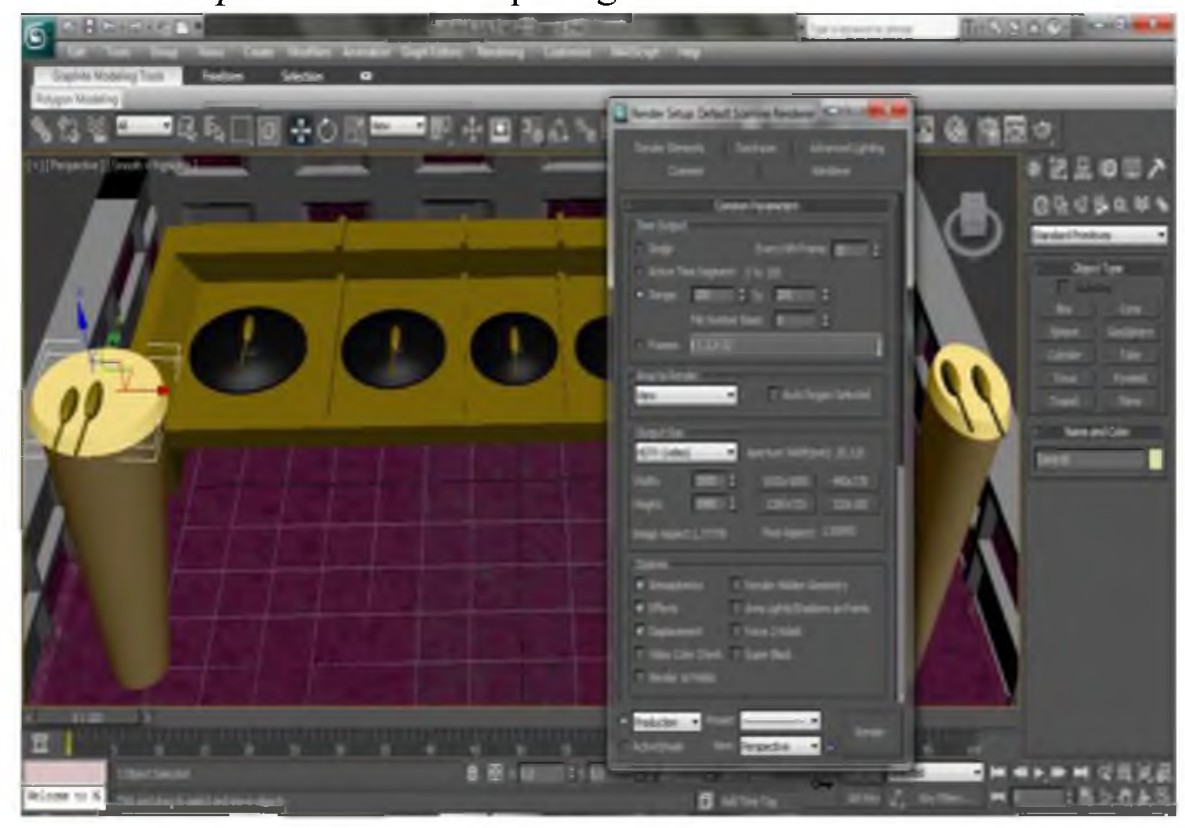

Gambar 8. Render Setup

Setelah muncul seperti gambar di atas atur durasi framenya yang berada di dalam menu render pada gambar 9 .

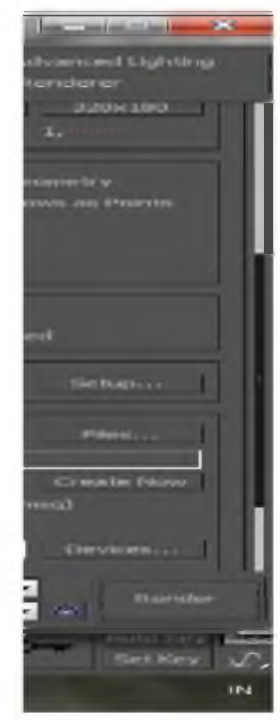

Gambar 9. Menu Files

lalu klik menu files akan muncul file penyimpanan files penyimpan ini disimpan dalam bentuk format avi seperti gambar 10 . 
Nurcahyani Dewi Retnowati, Kristina Nona

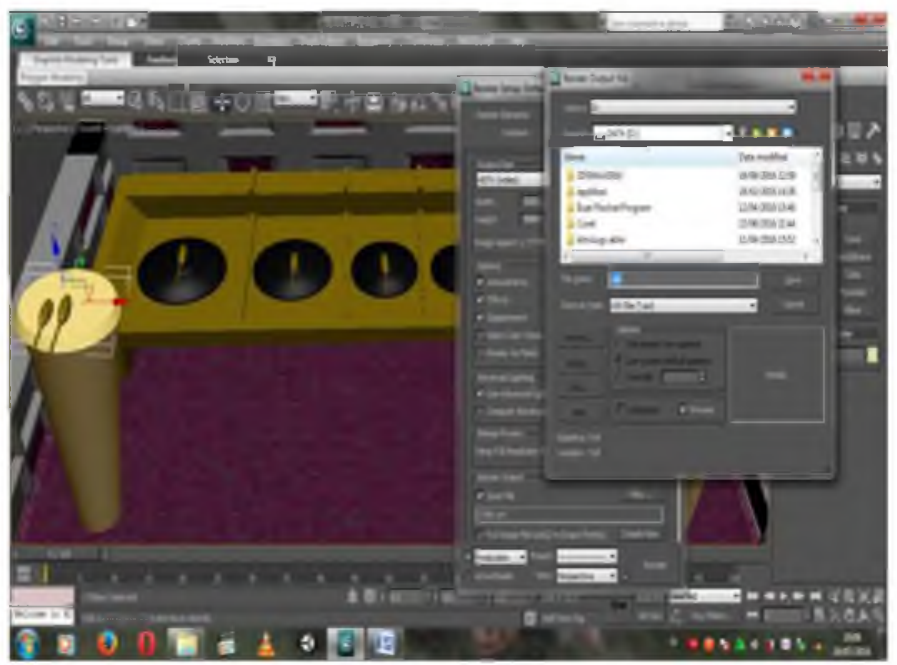

Gambar 10. File Penyimpanan Gong Dan Waning Yang Akan Di Render

Setelah itu pilih setup dan akan muncul seperti gambar 11.

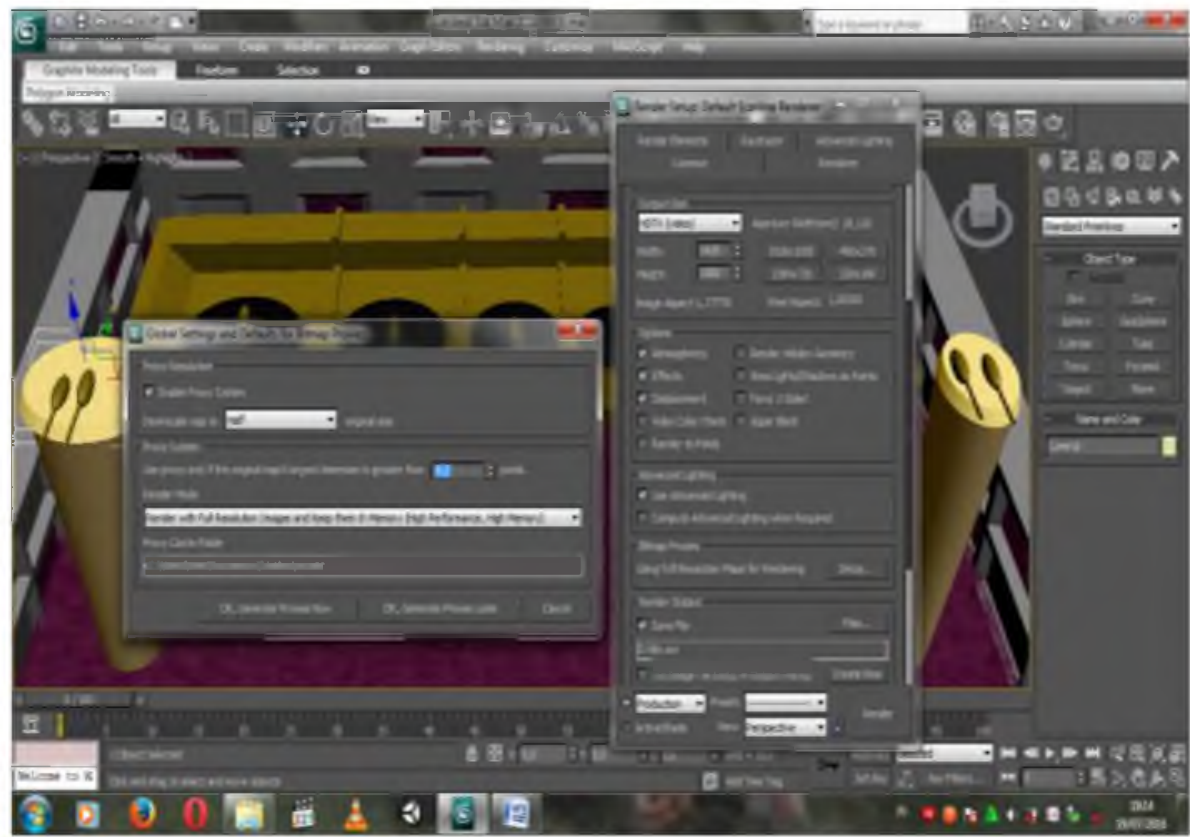

Gambar 11. Setting Render Setup

Setelah pilih setup akan muncul seperti gambar diatas lalu pilih ok generate poxies later, selanjutnya klik render akan muncul seperti gambar 12 . 


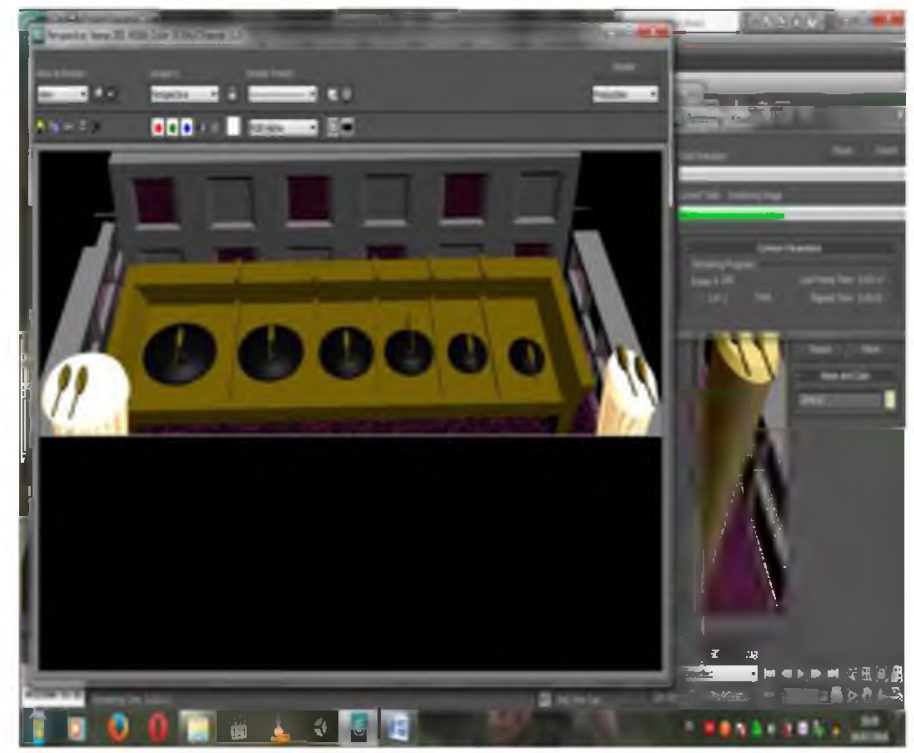

Gambar 12. Proses Rendering

Animasi yang sudah dirender sudah jadi dalam bentuk format avi seperti pada gambar 13 .

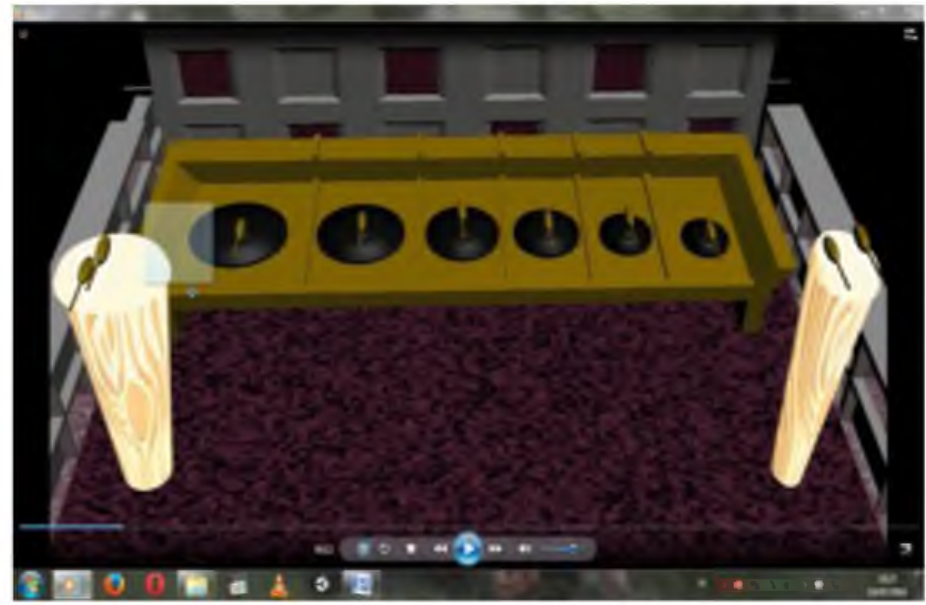

Gambar 13. Files Format $A v i$ Sudah Dirender

File yang sudah jadi format aviakan digabungkan lalu di-import ke dalam software wondershare filmora untuk mengedit video yang sudah di-render dalam bentuk frame dan meng-import bunyinya.

Tampilan dari Animasi Gong Waning yang telah jadi dapat dilihat pada gambar 14. 


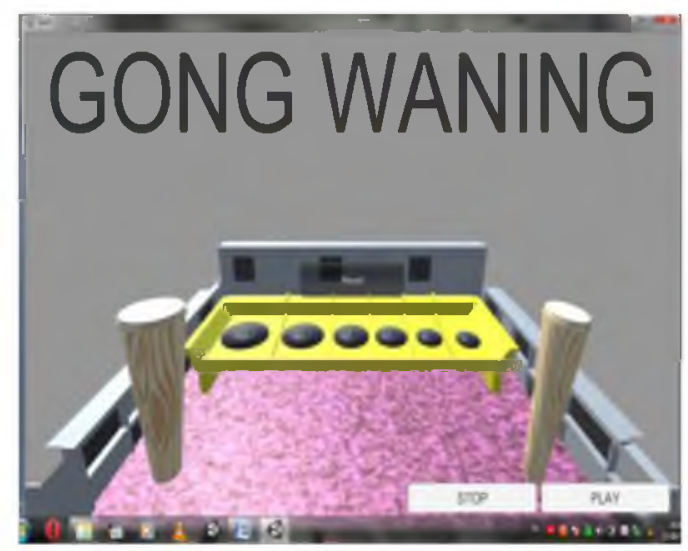

Gambar 14. Tampilan Animasi Gong Waning

\section{Kesimpulan dan Saran}

Berdasarkan hasil pembuatan visualisasi alat musik tradisional Gong Waning menggunakan animasi 3D dapat diambil beberapa kesimpulan sebagai berikut :

1. Aplikasi ini berupa Gong Waning yang dapat menghasilkan output berupa bunyi.

2. Merancang dan membuat bentuk pemodelan animasi pengenalan alat musik Gong Waning tradisional menggunakan 3Ds.Max dan pada bunyinya menggunakan software unity.

Adapun saran-saran untuk pengembangan aplikasiini adalah sebagai berikut :

1. Diharapkan dengan adanya aplikasi ini dapat menjadi salah satu solusi bagi masyarakat untuk semakin tertarik dalam menggenal dan memahami alat musik tradisional Gong Waning.

2. Aplikasi ini dapat dikembangkan lagi dan tidak hanya pada sistem berbasis desktop tetapi bisa dibawa ke android.

3. Seharusnya gerakan animasi kayu disaat memukul Gong Waning menghasilkan bunyi.

\section{DAFTAR PUSTAKA}

Andi. 2008. Editing Video dengan Wondershare Filmora. Andi Offset. Yogyakarta.

Bowo Dwi Ariyanto. 2014. Aplikasi Pengenalan Tata Surya Augmented Reality. Jurnal Teknik Elektro. Institut Teknologi Surabaya.

Iwan Setya Nugraha. 2014. Jurnal Pembelajaran PengenalanAlat Musik Piano. Jurnal Informatika. Jurusan Teknik Informatika. Universitas Kristen Maranatha.

Kendall, K.E., dan J.E. Kendall. 2003, Analisis dan Perancangan Sistem, Jakarta.

Mardi. 2011. Sistem Informasi Diagram Alir Sistem. Bogor: Penerbit Ghalia Indonesia. 
Mochamad Fathoni. 2012. Pengenalan Alat Musik Gamelan Berbasis Multimedia. Jurnal Teknik Informatika. Universitas Muhammadiyah Malang.

Peter H. 2007. 3D Studio Max Design 2010 Untuk Pemodelan 3Dimensi. Semarang: Wahana Komputer.

Wiliam Richard. 2009. Multimedia Digital Dasar Teori +Pengembangannya. Andi Offset. Yogyakarta 
Nurcahyani Dewi Retnowati, Kristina Nona 